\title{
Breastfeeding and childhood obesity in the Azores
}

\author{
ANA VAZ FERREIRA ${ }^{1,2, A-G}$, INÊS ROSENDO ${ }^{1,3, A-G}$, LUIZ MIGUEL SANTIAGO ${ }^{1,4, E, ~ F, ~ G ~}$ \\ ORCID ID: 0000-0002-7115-1880 ORCID ID: 0000-0001-8838-6021 ORCID ID: 0000-0002-9343-2827 \\ JOSÉ AUGUSTO SIMÕES3, 5, 6, A, D, E-G \\ ORCID ID: 0000-0003-2264-7086 \\ ${ }^{1}$ Faculty of Medicine, University of Coimbra, Portugal \\ ${ }^{2}$ Portuguese Oncology Institute of Porto (IPO Porto), Porto, Portugal \\ ${ }^{3}$ CINTESIS - Centre for Research in Health Technologies and Service, Porto, Portugal \\ ${ }^{4}$ CEISUC - Centre for Health Studies and Investigation of the University of Coimbra, Portugal \\ ${ }^{5}$ Faculty of Health Sciences, University of Beira Interior, Covilhã, Portugal \\ ${ }^{6}$ ARS Centro, Coimbra, Portugal
}

A - Study Design, B - Data Collection, C - Statistical Analysis, D - Data Interpretation, E - Manuscript Preparation, F - Literature Search, G - Funds Collection

Summary Background. The hypothesis that breastfeeding has a protective effect in childhood obesity is not new; however, controversial results have been published. Since the Azores reported the lowest rate of breastfeeding in Portugal and a high prevalence of childhood obesity, it becomes important to understand whether these facts are related or not.

Objectives. To investigate the relationship between breastfeeding and childhood obesity in a population of Azorean children. Material and methods. A cross-sectional study was carried out on 183 Azorean children between 5-10 years of age between September and December 2016. The weight and height of the children were measured at the consultation and other variables were investigated through a questionnaire. The association between breastfeeding and childhood obesity was tested using logistic regression models. Results. $18.6 \%$ of the children were obese and $74.3 \%$ were breastfed. The exclusive breastfeeding rate at 6 months was $3.3 \%$. Complementary breastfeeding was present in $39.3 \%$ at 6 months and $7.1 \%$ at 2 years. Obese children were breastfed less time than non-obese children, suggesting a dose-effect relationship $(p=0.025)$. We found a significant and independent relationship between infant obesity and total time of breastfeeding ( $\mathrm{RR}=0.906 ; 95 \% \mathrm{Cl}[0.842,0.974] ; p=0.008)$, physical activity $(\mathrm{RR}=0.883 ; 95 \% \mathrm{Cl}[0.801,0.972] ; p=$ $0.012)$ and maternal nutritional status ( $\mathrm{RR}=3.452 ; 95 \% \mathrm{Cl}[1.361,8.755] ; p=0.009)$.

Conclusions. Breastfeeding and physical activity behaved as protective factors for childhood obesity, while the nutritional status of the mother acted as a risk factor. Childhood obesity is a current problem in the Azores, and breastfeeding can be an effective, simple and affordable tool to reduce this.

Key words: breastfeeding, overweight, paediatric obesity, child health, Azores.

Vaz Ferreira A, Rosendo I, Santiago LM, Simões JA. Breastfeeding and childhood obesity in the Azores. Fam Med Prim Care Rev 2021; 23(1): 81-86, doi: https://doi.org/10.5114/fmpcr.2021.103151.

\section{Background}

The World Health Organization (WHO) classifies obesity as a $21^{\text {st }}$ century epidemic and estimates that in 2025, there will be about 70 million overweight or obese children under 5 years of age [1].

Portugal is one of the European countries with the highest prevalence of overweight and childhood obesity, although there has been a positive evolution in the last few years. The third phase of the Childhood Obesity Surveillance Initiative - Portugal (COSI - Portugal) revealed that $31.6 \%$ and $13.9 \%$ of children between 6 and 8 years old were overweight or obese, respectively [2]. In the same study, the Azores appeared as the region with the highest rate of overweight and obesity in 2010 but with a very significant improvement in $\mathbf{2 0 1 3}$ for these parameters.

The increase in the prevalence of childhood obesity is worrisome, since $60 \%$ of obese children will suffer from obesity in adulthood [2]. Obesity is a known risk factor for several chronic non-transmissible diseases, such as type 2 diabetes, hypertension, dyslipidaemia, sleep apnoea, orthopaedic pathology, among others. In addition, they are more prone to discrimination, social isolation and low self-esteem. In some studies, childhood obesity has also been associated with decreased school performance [3]. The difficulties inherent to the treatment of obesity highlight the importance of identifying preventive measures that can be effective, simple, cost effective and without adverse effects [4].

The hypothesis that breastfeeding (BF) has a protective effect against obesity is not new in literature, and it is also theorised that it has a clear dose-response relationship [5, 6]. However, controversial results have been found, requiring further studies on this subject $[7,8]$.

The WHO points out several advantages of breastfeeding for both child and mother, including childhood obesity reduction, and has launched the goal to increase exclusive breastfeeding until 6 months of age to $50 \%$ in 2025 [9].

Why is breastfeeding (BF) a protective factor for childhood obesity? It is known that human milk provides a balanced and adequate number of calories and nutrients to a child as their composition changes over time. In turn, formula milk contains higher levels of proteins and fats, which are responsible for greater adiposity. Another advantage of human milk is that it contains lower levels of leptin and ghrelin, appetite-regulating hormones which correlatd positively with fat mass percentage [10].

In Portugal, the rates of exclusive breastfeeding up to 6 months of age and complementary breastfeeding up to 2 years of age are far below desirable levels. Although the rate of initiation of breastfeeding is greater than $90 \%$, exclusive breastfeed- 
ing at 6 months falls to $1.8 \%$, and the rate of breastfeeding at 2 years decreases to 1.5\% [11]. Regarding this data, the Azores presents the lowest rates in the country [12]. Portuguese studies that test this relationship are still scarce $[6,13]$, and to date no study has been published about this theme in the Azores. Since this region had the lowest rats of breastfeeding in the country and was the region with the highest rate of overweight and childhood obesity in 2010, it is important to try to understand the current reality and whether these facts are related or not.

Therefore, the main objective of this study is to investigate the relationship between breastfeeding and childhood obesity in a population of Azorean school-age children. This study also aims to characterise the prevalence and duration of breastfeeding (exclusive breastfeeding up to 6 months and breastfeeding up to 2 years), the prevalence of overweight and childhood obesity and to investigate the influence of other variables on the nutritional state of childree.

\section{Material and methods}

\section{Design}

A cross-sectional study was carried out in a population of children from the Autonomous Region of the Azores. Authorisation from the National Data Protection Commission, the Ethics Committee and the Island Health Units, through their representatives, was acquired.

\section{Setting}

The collection of data, from a convenience sample, took place through volunteer local researchers in Primary Care Units of Health (PCUH) from September to December 2016.

\section{Sample}

The study was carried out in a population of children between 5 and 10 years of age during a routine child health consultation in PCUH.

According to the last phase of the COSI, the rate of childhood obesity in the Azores was $10 \%$; therefore, it was estimated that a minimum sample of 138 children for this study was needed (calculator used available at http://www.raosoft.com/ samplesize.html, using $5 \%$ margin of error and $95 \%$ confidence interval). Because of eventual withdrawals, a total sample of 200 children was the initial target, considering the number of children enrolled in each Island Health Unit (IHU) and making a proportional distribution (Table 1 ).

\section{Measurement}

Body Mass Index (BMI) was calculated using the formula "BMI $=$ weight $(\mathrm{kg}) /$ height $^{2}(\mathrm{~m})$ " and its value rounded to the hundredths, in accordance with the rules of international biostatistics. Child BMI percentiles were classified according to the WHO curves used in the National Program of Child and Youth Health 2013 for age and gender, which defines "overweight" as a BMI percentile $\geq 85$ and $<97$ and "obesity" as a BMI percentile $\geq 97$ [14]. The presence of breastfeeding (exclusive and complementary) and its duration were investigated. The gestation time was classified as "preterm" (< 37 weeks), "term" (37-42 weeks) or "post-term" ( $\geq 42$ weeks). The presence or absence of gestational diabetes and maternal smoking habits during pregnancy were also considered. Birth weight was categorised as "low birth weight" $(<2,500 \mathrm{~g})$, "normal birth weight" $(\geq 2,500$ and $<4,000 \mathrm{~g}$ ) and "foetal macrosomia" ( $\geq 4,000 \mathrm{~g})$.

The nutritional status of the mother at the time of the study was classified as underweight $\left(\mathrm{BMI}<18.5 \mathrm{~kg} / \mathrm{m}^{2}\right)$, normal weight (BMI $18.5-24.9 \mathrm{~kg} / \mathrm{m}^{2}$ ) or overweight/obesity (BMI $\geq 25$ $\mathrm{kg} / \mathrm{m}^{2}$ ). The mother's schooling was classified in 4 categories according to the number of years $(<4$; 4-9 years; 9-12 or $\geq 12$ years). The habits of children were also investigated, such as their daily physical activity, including walking and playing outdoors, and time spent watching TV, both in hours per week.

\section{Data collection}

During the consultation, the weight and height of the children were evaluated, and a questionnaire was given to the parents to assess the following variables: gestation time, gestational diabetes, maternal smoking habits during pregnancy, birth weight, breastfeeding, children's habits (physical activity and time spent watching television) and the nutritional status and schooling years of the mother.

Anonymity and confidentiality were ensured throughout the investigation. The free and informed consent of the legal representative of the child was obtained on the same day, and participation was voluntary.

\section{Data analysis}

Descriptive and inferential statistical analyses were performed using a significance level of $\alpha=0.05$ and power 1- $6=$ $80 \%$. The primary endpoint (relationship between breastfeeding and overweight in infants) was tested using chi-square and Mann-Whitney $U$ tests and multivariate analysis with logistic regression. Subgroup analysis was also performed.

\begin{tabular}{|c|c|c|c|c|c|c|c|c|}
\hline \multirow[t]{2}{*}{ IHU } & \multicolumn{6}{|c|}{ Number of children by age (years) ${ }^{a}$} & \multirow[t]{2}{*}{ Total } & \multirow[t]{2}{*}{ Sample } \\
\hline & 5 & 6 & 7 & 8 & 9 & 10 & & \\
\hline São Miguel & 1,761 & 1,778 & 1,805 & 1,728 & 1,729 & 1,839 & 10,640 & 125 \\
\hline Santa Maria & 57 & 56 & 61 & 56 & 69 & 59 & 358 & 4 \\
\hline Terceira & 566 & 517 & 551 & 597 & 537 & 596 & 3,364 & 40 \\
\hline Faial & 163 & 133 & 160 & 155 & 139 & 162 & 912 & 11 \\
\hline Pico & 133 & 115 & 117 & 121 & 119 & 149 & 754 & 9 \\
\hline São Jorge & 79 & 80 & 89 & 91 & 90 & 90 & 519 & 6 \\
\hline Graciosa & 42 & 48 & 35 & 47 & 37 & 38 & 247 & 3 \\
\hline Flores & 26 & 35 & 29 & 44 & 39 & 34 & 207 & 3 \\
\hline Corvo & 4 & 3 & 4 & 2 & 2 & 3 & 18 & 1 \\
\hline Total & 2,831 & 2,765 & 2,851 & 2,841 & 2,761 & 2,970 & 17,019 & 202 \\
\hline
\end{tabular}




\section{Results}

\section{Characteristics of the sample}

Data was collected from a sample of 183 children from the nine islands of the Azores (Table 2), with a mean age of $7.23 \pm$ 1.78 years, of which $58.5 \%$ were female (Table 3 ).

\begin{tabular}{|c|c|c|}
\hline Island Health Unit & $n(\%)$ & $\begin{array}{l}\text { Number of children between } \\
5 \text { and } 10 \text { years of age (\%) }\end{array}$ \\
\hline São Miguel & $87(47.5)$ & $10,640(62.5)$ \\
\hline Santa Maria & $4(2.2)$ & $358(2.1)$ \\
\hline Terceira & 40 (21.9) & 3,364 (19.8) \\
\hline Faial & $11(6.0)$ & $912(5.4)$ \\
\hline Pico & $27(14.8)$ & $754(4.4)$ \\
\hline São Jorge & $6(3.3)$ & 519 (3.0) \\
\hline Graciosa & $3(1.6)$ & $247(1.5)$ \\
\hline Flores & $4(2.2)$ & $207(1.2)$ \\
\hline Corvo & $1(0.5)$ & $18(0.1)$ \\
\hline Total & 183 & 17,019 \\
\hline
\end{tabular}

\begin{tabular}{|c|c|}
\hline Characteristics & $n(\%)$ \\
\hline $\begin{array}{l}\text { Gender } \\
\text { male } \\
\text { female }\end{array}$ & $\begin{array}{l}76(41.5) \\
107(58.5)\end{array}$ \\
\hline $\begin{array}{l}\text { Birth weight } \\
\text { low weight } \\
\text { adequate weight } \\
\text { macrosomia }\end{array}$ & $\begin{array}{l}18(9.8) \\
160(87.4) \\
5(2.7)\end{array}$ \\
\hline $\begin{array}{l}\text { Gestation time } \\
\text { premature } \\
\text { term } \\
\text { post-term }\end{array}$ & $\begin{array}{l}10(5.5) \\
170(92.9) \\
3(1.6)\end{array}$ \\
\hline $\begin{array}{l}\text { Gestational diabetes } \\
\text { absent } \\
\text { present }\end{array}$ & $\begin{array}{l}172(94.0) \\
11(6.0)\end{array}$ \\
\hline $\begin{array}{l}\text { Maternal smoking habits during pregnancy } \\
\text { absent } \\
\text { present }\end{array}$ & $\begin{array}{l}155 \text { (84.7) } \\
28(15.3)\end{array}$ \\
\hline $\begin{array}{l}\text { Nutritional status of the child } \\
\text { low weight } \\
\text { normal } \\
\text { overweight } \\
\text { obesity }\end{array}$ & $\begin{array}{l}4(2.2) \\
107(58.5) \\
38(20.8) \\
34(18.6)\end{array}$ \\
\hline $\begin{array}{l}\text { Nutritional status of the mother } \\
\text { low weight } \\
\text { normal } \\
\text { overweight } \\
\text { obesity }\end{array}$ & $\begin{array}{l}2(1.1) \\
69(37.7) \\
62(33.9) \\
50(27.3)\end{array}$ \\
\hline $\begin{array}{l}\text { Mother's schooling } \\
\quad<4 \text { years } \\
\geq 4 \text { and }<9 \text { years } \\
\geq 9 \text { and }<12 \text { years } \\
\geq 12 \text { years }\end{array}$ & $\begin{array}{l}2(1.1) \\
55(30.1) \\
36(19.7) \\
90(49.2)\end{array}$ \\
\hline
\end{tabular}

Regarding the nutritional status of the studied sample, a prevalence of obesity of $18.6 \%$ and overweight of $20.8 \%$ was observed.

In relation to the habits of the children, it was found that they spend on average $7.41 \pm 6.52$ hours a week in physical activity and $10.45 \pm 6.92$ hours a week watching television.
The mothers had a mean age of $36.3 \pm 5.89$ years, and $68.9 \%$ had 9 or more years of schooling. Regarding the nutritional status, they had a mean BMI of $27.52 \pm 5.99 \mathrm{~kg} / \mathrm{m}^{2}$, and $61.2 \%$ were overweight or obese $\left(B M I \geq 25 \mathrm{~kg} / \mathrm{m}^{2}\right)$.

In the studied population, the breastfeeding (BF) rate was $74.3 \%$, decreasing to $42.6 \%$ at 6 months and to $7.1 \%$ at 2 years. The exclusive breastfeeding rate (EBF) up to 3 months was $44.3 \%$, but only $3.3 \%$ of the children studied received EBF until 6 months of age (Table 4). On average, children received EBF for 9.9 weeks, $95 \% \mathrm{Cl}[8.4,11.4]$ and complementary breastfeeding (CBF) for 7.38 months, Cl 95\% [3.6, 6.2].

\begin{tabular}{|l|l|}
\hline \multicolumn{2}{|l|}{ Table 4. Prevalence of breastfeeding in the sample $(\boldsymbol{n}=183)$} \\
\hline & $n(\%)$ \\
\hline $\begin{array}{l}\text { Breastfeeding } \\
\text { absent } \\
\text { present }\end{array}$ & $47(25.7)$ \\
\hline $\begin{array}{l}\text { Exclusive breastfeeding } \\
\text { at } 3 \text { months }\end{array}$ & $136(74.3)$ \\
at 6 months & $81(44.3)$ \\
\hline $\begin{array}{l}\text { Complementary breastfeeding } \\
\text { at } 6 \text { months } \\
\text { at } 2 \text { years }\end{array}$ & $6(3.3)$ \\
\hline
\end{tabular}

${ }^{a}$ Categories of Exclusive breastfeeding are not mutually exclusive; ${ }^{b}$ Categories of Complementary breastfeeding are not mutually exclusive.

\section{Association between obesity and breastfeeding}

In the bivariate analysis, a statistically significant association was found between childhood obesity and complementary breastfeeding (CBF) $\geq 6$ months ( $p=0.036$ ). In addition, childhood obesity was significantly associated with the nutritional status of the mother $(p=0.016)$. There was no statistically significant association between childhood obesity and other variables considered in this study (gender, gestation time, birth weight, gestational diabetes, maternal smoking habits during pregnancy and number of years of mother's education) (Table 5).

\begin{tabular}{|c|c|c|}
\hline \multirow[t]{2}{*}{ Variables } & \multicolumn{2}{|c|}{ Obese children $(n=50)$} \\
\hline & $\%$ & $p$ \\
\hline $\begin{array}{c}\text { Gender } \\
\text { male } \\
\text { female }\end{array}$ & \begin{tabular}{|l|}
15.8 \\
20.6 \\
\end{tabular} & 0.413 \\
\hline $\begin{array}{l}\text { Gestation time } \\
\text { premature } \\
\text { term } \\
\text { post-term }\end{array}$ & \begin{tabular}{|l|}
10.0 \\
18.8 \\
33.3 \\
\end{tabular} & 0.630 \\
\hline $\begin{array}{l}\text { Birth weight } \\
\text { low weight } \\
\text { adequate weight } \\
\text { macrosomia }\end{array}$ & \begin{tabular}{|l|}
16.7 \\
17.5 \\
60.0 \\
\end{tabular} & 0.054 \\
\hline $\begin{array}{l}\text { Gestational diabetes } \\
\text { present } \\
\text { absent }\end{array}$ & \begin{tabular}{|l|}
36.4 \\
17.4 \\
\end{tabular} & 0.118 \\
\hline $\begin{array}{l}\text { Smoking habits during pregnancy } \\
\text { present } \\
\text { absent }\end{array}$ & \begin{tabular}{|l|}
25.0 \\
17.4 \\
\end{tabular} & 0.343 \\
\hline $\begin{array}{l}\text { Exclusive breastfeeding } \\
\geq 3 \text { months } \\
\geq 6 \text { months }\end{array}$ & $\begin{array}{l}13.6 \\
0.0 \\
\end{array}$ & $\begin{array}{l}0.121 \\
0.234\end{array}$ \\
\hline $\begin{array}{l}\text { Complementary breastfeeding } \\
\geq 6 \text { months } \\
\geq 2 \text { years }\end{array}$ & \begin{tabular}{|l|}
11.1 \\
0.0
\end{tabular} & $\begin{array}{l}0.036^{*} \\
0.074\end{array}$ \\
\hline
\end{tabular}




\begin{tabular}{|c|c|c|}
\hline Variables & \multicolumn{2}{|c|}{ Obese children $(n=50)$} \\
\hline $\begin{array}{l}\text { Nutritional status of the mother } \\
\text { low weight/normal } \\
\text { overweight/obesity }\end{array}$ & $\begin{array}{l}9.9 \\
24.1\end{array}$ & $0.016^{*}$ \\
\hline $\begin{array}{l}\text { Mother's schooling } \\
<9 \text { years } \\
\geq 9 \text { years }\end{array}$ & $\begin{array}{l}21.1 \\
17.5\end{array}$ & 0.563 \\
\hline
\end{tabular}

${ }^{*} p<0.05$.

The prevalence of obesity was higher for children with EBF $<6$ months (19.2\%) compared to those who received EBF $\geq 6$ months $(0 \%)$. If we consider the total time of breastfeeding, it was verified that the prevalence of obesity was higher in children breastfed less than 2 years $(20 \%)$ when compared to those who received human milk for a period $\geq 2$ years $(0 \%)$.

In the bivariate analysis of quantitative variables, a significant relationship between obesity and exclusive breastfeeding ( $p=0.039)$, breastfeeding total time $(p=0.015)$, daily physical activity $(p=0.031)$ and maternal BMI $(p<0.001)$ were observed (Table 6).

\begin{tabular}{|c|c|c|c|}
\hline & $\begin{array}{l}\text { Obese } \\
\text { M (SD) }\end{array}$ & $\begin{array}{l}\text { Not obese } \\
\text { M (SD) }\end{array}$ & $p$ \\
\hline Child age ${ }^{a}$ & $7.56(1.73)$ & 7.15 (1.78) & 0.208 \\
\hline $\begin{array}{l}\text { Exclusive breast- } \\
\text { feeding }^{\text {b }}\end{array}$ & $6.53(7.20)$ & $10.69(11.04)$ & $0.039^{*}$ \\
\hline $\begin{array}{l}\text { Total time of } \\
\text { breastfeeding }\end{array}$ & $3.34(4.48)$ & 8.30 (11.29) & $0.015^{*}$ \\
\hline $\begin{array}{l}\text { Daily physical } \\
\text { activity }^{d}\end{array}$ & $4.72(2.91)$ & $8.02(6.95)$ & $0.031^{*}$ \\
\hline $\begin{array}{l}\text { Time spent watch- } \\
\text { ing TV }\end{array}$ & $10.99(7.52)$ & $10.33(6.79)$ & 0.620 \\
\hline $\begin{array}{l}\text { Nutritional status } \\
\text { of the mother }\end{array}$ & $31.69(6.64)$ & $26.57(5.43)$ & $<0.001^{*}$ \\
\hline
\end{tabular}

${ }^{*} p<0.05,{ }^{a}$ age in years, ${ }^{b}$ time in weeks, ${ }^{c}$ time in months, ${ }^{d}$ time in hours per week, ${ }^{\mathrm{e}}$ Body Mass Index $\left(\mathrm{kg} / \mathrm{m}^{2}\right)$.

After multivariate analysis, to exclude confounding variables, it was found that obesity maintained a significant and independent relationship with total time of breastfeeding, the physical activity of the child and the nutritional status of the mother. Thus, maternal nutritional status was identified as an independent risk factor for infant obesity, and total time of breastfeeding and physical activity of the child were identified as independent protective factors (Table 7).

\begin{tabular}{|c|c|c|c|}
\hline & RR & $95 \% \mathrm{Cl}$ & $p$ \\
\hline $\begin{array}{l}\text { Total time of breastfeed- } \\
\text { ing }\end{array}$ & 0.906 & $0.842-0.974$ & $0.008^{*}$ \\
\hline Daily physical activity & 0.883 & $0.801-0.972$ & $0.012^{*}$ \\
\hline $\begin{array}{l}\text { Nutritional status of the } \\
\text { mother }\end{array}$ & 3.452 & $1.361-8.755$ & $0.009^{*}$ \\
\hline
\end{tabular}

${ }^{*} p<0.05$.

\section{Discussion}

The aim of this study was to verify whether there is an association between breastfeeding and childhood obesity, and we saw that children breastfed for less than 6 months tended to be more obese (23.4\%) than the remaining $11.1 \%$. If we look at the rate of obesity in children who have been breastfed for a period of $\geq 2$ years, it was found to be lower $(0 \%)$ than those breastfed for less time (20\%). This data is similar to that found by Simon et al. [7], who verified that EBF $\geq 6$ months and $C B F \geq 2$ years are independent protective factors of childhood obesity and that the longer the breastfeeding period, the greater the protective effect. Our results also support the hypothesis of a relationship between breastfeeding duration and childhood obesity $(p=0.015)$, since obese children, on average, were breastfed almost less than half the time of non-obese children (3.34 and 8.30 months, respectively).

We found an independent and significant relationship between childhood obesity and three of the studied variables: BF, physical activity of children and nutritional status of the mother, with the first two acting as protective factors and the latter as a risk factor. The protective effect of BF is supported by a meta-analysis [5], which included 25 studies conducted from 1997 to 2014 , on 226,508 children from 12 different countries, where $\mathrm{BF}$ was found to be associated with a decreased risk of childhood obesity ( $A O R=0.78 ; 95 \% \mathrm{Cl}: 0.74-0.81$ ). They also found that there is a dose-response effect between duration of $\mathrm{BF}$ and obesity. This dose-effect relationship is of greater significance for $\mathrm{BF} \geq 7$ months. When $\mathrm{BF}$ is less than 3 months, this protective effect is lower [5].

In the sample of Azorean children included in the study ( $n=$ 183), a total prevalence of overweight plus obesity of $39.4 \%$ was found. This rate is higher than that reported by COSI-Portugal [2] for the same region in 2013 (24\%). Additionally, our data is higher than that revealed by another recent Portuguese study on 1,433 children, where a prevalence of overweight and obesity of $33 \%$ was found [15].

From 2010 to 2013, the Azores was the Portuguese region with a greater decrease in the rate of overweight, from $40.5 \%$ to $24 \%$, which can be explained by the intervention and application of obesity approach programmes [2]. The difference found may be explained by the fact that COSI-Portugal and our study included children in different age groups: $6-8$ years and $5-10$ years of age, respectively. In addition, our study included children from all 9 islands of the archipelago, which was not verified in the COSI, the data of which was collected only in 4 schools.

Regarding obesity, we found a prevalence of $18.6 \%$, higher than the previously published rate of $10 \%$ for the same region [2], as well as from other Portuguese regions, where a prevalence of childhood obesity of $10.7 \%$ [15] and $11.6 \%$ [8] was reported.

In our study, on average, obese children spent less time per week on physical activities compared to non-obese children (4.72 and 8.02 hours per week, respectively). In multivariate analysis, this relationship was independent and statistically significant (RR: $0.883 ; 95 \% \mathrm{Cl}[0.801,0.972] ; p=0.012$ ). Although there was a difference, the relationship between the time spent watching TV and the children's BMI percentile was not significant in the present study. Obese and non-obese children spent, on average, 10.99 and 10.33 hours per week in front of the TV. This result is divergent to that found in other studies, where the time spent watching TV influenced the sedentary/ /physical activity balance, favouring the first, which is related to a higher prevalence of overweight [8]. It seems that, in this specific population, it will be more important to promote the benefits of physical activity and to encourage children to have an active lifestyle than to focus only on reduction of their time spent watching TV.

It is interesting to note that most mothers were overweight or obese (61.2\%), a number that is significantly higher than that 
found in other Portuguese studies $(24.8 \%$ in a Lisbon sample [6], $33.5 \%$ in a Coimbra sample [13] and $29.3 \%$ in the Azores [16]). We found a relationship between the nutritional status of the mother and child. Childhood obesity may have multiple causes, including genetic factors, personal behaviours, dietary habits and their interactions [5]; thus, the overweight/obesity of the mother can be a risk factor for childhood obesity, explained by both genetic and environmental factors (especially eating habits and patterns of physical activity). Once again, the importance of physical activity is present, and actions must be taken actions to promote this among the entire family. Special attention should be paid to obese women who want to get pregnant, since their child will have a higher probability of being obese, independent of being breastfed or not.

We found an initial BF rate of $74.3 \%$, similar to two other Portuguese studies $[6,17]$, but this was lower than most published Portuguese data, where breastfeeding rates between 84-99\% were described $[11,12,18]$.

In our sample, the mean duration of breastfeeding was around 7 months. About $39 \%$ of the children received human milk up to 6 months of age, and $7.1 \%$ received human milk up to 2 years of age. These numbers fall short of WHO goals for a 6-month-old child, where a BF prevalence of at least $50 \%$ is recommended [19]. The WHO recommends that BF should start in the first hour of life, be exclusive up to 6 months and complementary until 2 years of age, but estimates show that only $38 \%$ of children globally received EBF [19] at 6 months, and only $44 \%$ received human milk in the first hour postpartum [20]. In our sample, about half $(44.3 \%)$ of the children were exclusively breastfed at 3 months of age, but only $3.3 \%$ were exclusively breastfed until 6 months of age. A recent study carried out on the island of São Miguel revealed a 17.7\% prevalence of BF at 6 months of age and points out the 3 leading reasons for BF discontinuation: poor lactation (71.7\%), mom disliking BF (26.1\%) and baby crying from hunger (17.4\%) [17]. Another study [12] that included 494 Portuguese children born in 2011 found that $96 \%$ of the mothers started breastfeeding, but at the end of the first week postpartum, this percentage dropped to $72.7 \%$, at 3 months to $33.2 \% \mathrm{EBF}$ and to $0.9 \%$ at 6 months of age. In this same study, the mother's information about the advantages of breastfeeding, the use of BF support spaces in healthcare units and the delivery occurred in a Baby-Friendly Hospital influenced the success of breastfeeding. These facts emphasise the importance of family physicians in enabling and supporting the mother in this matter, both in maternal health consultations and in the first consultations of the new-born child.

\section{Limitations of the study}

The study presented here has some limitations. The study sample was smaller than the initially target of 200 children, with a slight underrepresentation of São Miguel island and an overrepresentation of the islands of Flores and Pico. Even so, the total sample was representative of the study population.

The data was collected through a questionnaire based on the information provided by the mother, which may have conditioned a performance and memory bias, mainly about the duration of breastfeeding. In addition, the fact that the data was collected by several collaborators may have conditioned the interviewer's bias and measurement bias, since a non-validated questionnaire was used, and the exact form of assessment of the children's weight and height is unconfirmed. These biases can be minimised in future studies using standardised questionnaires, trained collaborators and using the same material to measure anthropometric parameters.

Another limitation was that a cross-sectional study was performed, and thus the nutritional status of the children refers only to the time of consultation and may not reflect the true influence of breastfeeding on their growth and development. A causal relationship cannot be concluded from this kind of study.

With this study, we wanted to evaluate other variables that could influence childhood obesity; however, not all possibilities were explored (such as the dietary habits), which may have influenced the results. Breastfeeding is important as a recommendation for a better maternal-child relationship, for economic reasons, as well as for health reasons that may prevent obesity in the future.

\section{Conclusions}

We conclude that childhood obesity is a current problem in the Azorean reality, and for the studied population, breastfeeding has been a protective factor. Thus, we believe that the promotion of breastfeeding may be an effective, simple, affordable and inexpensive tool that can help to reduce childhood obesity in school-age children.

Acknowledgments. Thanks to the parents and children involved and to Ana Bettencourt, Ana Melo, Andrea Melo, Carina Silva, Catarina Medeiros, Cátia Aguiar, Conceição Carreiro, Cristina Cordeiro, Cristina Santos, Goretti Bazídio, Isabel Amaral, João Duarte, Liliane Dancov, Lúcia Marques, Luís Oliveira, Madeleine Stokreef, Margarida Pinheiro, Maria Melo, Maria Garcia, Maria Silveira, Maria Cordeiro, Mariana Oliveira, Marlene Areias, Marlene Melo, Natália Mendonça, Natércia Bairos, Olívia Rego, Regina Seco, Sandra Nunes, Sara Gaião, Sara Pardal, Sara Picanço, Susana Rego, Tânia Bairos, Tânia Cortez, Tércio Maio, Xéni Terra and Zilda Paiva, who collaborated in data collection.

Source of funding: This work was funded from the authors' own resources.

Conflicts of interest: The authors declare no conflicts of interest.

\section{References}

1. WHO, Commission on Ending Childhood Obesity. Facts and figures on childhood obesity. 2019 [Internet]. Geneva: World Health Organization [cited 7.04.2020]. Available from URL: http://www.who.int/end-childhood-obesity/facts/en.

2. Rito Al, Graça P. Childhood obesity surveillance initiative. COSI Portugal 2013. Lisboa: Instituto Nacional de Saúde Doutor Ricardo Jorge. 2015 (in Portuguese).

3. Wu N, Chen Y, Yang J, et al. Childhood obesity and academic performance: the role of working memory. Front Psychol 2017; 8: 611, doi: 10.3389/fpsyg.2017.00611.

4. Balaban G, Silva GAP. Protective effect of breastfeeding against childhood obesity. Jornal de Pediatria 2004; 80(1): 7-16, doi: 10.1590/ S0021-75572004000100004.

5. Yan J, Liu L, Zhu Y, et al. The association between breastfeeding and childhood obesity: a meta-analysis. BMC Public Health 2014; 14: 1267, doi: 10.1186/1471-2458-14-1267.

6. Ferraria N, Rodrigues V, Macedo L. Aleitamento materno e excesso de peso em crianças na idade escolar. Scientia Medica (Porto Alegre) 2013; 23(2): 75-81 (in Portuguese).

7. Simon VGN, Souza JMP, Souza SB. Breastfeeding, complementary feeding, overweight and obesity in pre-school children. Revista Saude Publica 2009; 43(1): 60-69, doi: 10.1590/S0034-89102009000100008.

8. Gomes S, Espanca R, Gato A, et al. Obesidade em idade pré-escolar - cedo demais para pesar demais! Acta Med Port 2010; 23(3): 371-378 (in Portuguese). 
9. WHO. Infant and young child feeding. 2018 [Internet]. Geneva: World Health Organization [cited 7.04.2020]. Available from URL: http://www.who.int/mediacentre/factsheets/fs342/en/.

10. Breij LM, Mulder MT, van Vark-van der Zee LC, et al. Appetite-regulating hormones in early life and relationships with type of feeding and body composition in healthy term infants. Eur J Nutr 2017; 56(4): 1725-1732, doi: 10.1007/s00394-016-1219-8.

11. Gaspar J, Luz A, Gomes S, et al. Aleitamento Materno - Ainda Longe do Desejável. Acta Pediatrica Portuguesa 2015; 46: 318-325 (in Portuguese).

12. Alarcão V, Ferreira I, Simões R, et al. Fatores relacionados com o aumento da prevalência e exclusividade do aleitamento materno em Portugal nos primeiros 6 meses de vida. Revista SPCNA 2012; 18(2): 53 (in Portuguese).

13. Silva CA. Aleitamento materno como fator protetor contra obesidade e excesso de peso infantil [dissertation]. Coimbra: Faculty of Medicine, University of Coimbra; 2014 (in Portuguese).

14. WHO. Growth reference data for 5-19 years. 2007 [Internet]. Geneva: World Health Organization [cited 7.04.2020]. Available from URL: http://www.who.int/growthref/en/.

15. Albuquerque D, Nobrega C, Samouda $\mathrm{H}$, et al. Assessment of obesity and abdominal obesity among Portuguese children. Acta Medica Portuguesa 2012; 25(3): 169-173.

16. Direção Regional de Saúde, Instituto Nacional de Saúde Dr. Ricardo Jorge. Inquérito Regional de Saúde dos Açores, 2014. 2015 [Internet]. Ponta Delgada: Government of Azores Islands [cited 7.04.2020]. Available from URL: https://www.azores.gov.pt/NR/ rdonlyres/7F84674B-B647-4AA4-A0D2-419806BBB8B2/920591/ResultadospreliminaresInReS1.pdf (in Portuguese).

17. Bairos T, Carvalho J, Valente F, et al. Prevalence and conditioning factors for breastfeeding in São Miguel Island. Proceedings of WONCA Europe Conference 2016; Copenhagen, Denmark.

18. Correia T, Carvalho C, Dias T, et al. Aleitamento materno e obesidade em crianças pré-escolares. Proceedings of XIV Encontro Nacional APEO 2011; Braga, Portugal (in Portuguese).

19. WHO/UNICEF. Global Nutrition Targets 2025: Breastfeeding Policy Brief (WHO/NMH/NHD/14.7). 2014 [Internet]. Geneva: World Health Organization [cited 7.04.2020]. Available from UR: http://apps.who.int/iris/bitstream/10665/149022/1/WHO_NMH_NHD_14.7_eng. pdf.

20. UNICEF/WHO. Breastfeeding Advocacy Initiative - for the best start in life. 2015 [Internet]. New York: United Nations Children's Fund [cited 7.04.2020]. Available from URL: http://apps.who.int/iris/bitstream/10665/152891/1/WHO_NMH_NHD_15.1_eng.pdf.

Tables: 7

Figures: 0

References: 20

Received: 26.02 .2020

Reviewed: 15.03 .2020

Accepted: 11.05.2020

Address for correspondence:

José Augusto Simões, MD, PhD, Assoc. Prof.

Faculty of Health Sciences

University of Beira Interior

Rua Teofilo Braga, 25, 5 Dto

3030-076 Coimbra

Portugal

Tel.: +351924406127

E-mail: jars@fcsaude.ubi.pt 